\title{
Internal Control Quality and Underinvestment under the Perspective of Corporate Life Cycle
}

\author{
Liu Yan ${ }^{1}$ \\ ${ }^{1}$ SHU-UTS SILC Business School, Shanghai University, Shanghai, China \\ Correspondence: Liu Yan, SHU-UTS SILC Business School, Shanghai University, NO.20 Chengzhong Rd., \\ Jiading Dist., Shanghai, China. Tel: 185-1652-5607. E-mail: Inuliuyan@163.com
}

Received: March 8, 2016

Accepted: March 29, 2015

Online Published: May 25, 2016

doi:10.5539/ijef.v8n6p141

URL: http://dx.doi.org/10.5539/ijef.v8n6p141

\begin{abstract}
This study examines the impact of internal control quality on corporate underinvestment from the perspective of dynamic development at different stages of life cycle, based on the sample of Chinese listed companies. I show that: at the growing stage, corporate underinvestment is mainly caused by financing constraints, at the maturity stage and recession stage, corporate underinvestment is caused by financing constraints and different kinds of agency conflicts. I also find that at different stages of life cycle, the impact of internal control quality on underinvestment is different. At the growing stage, the impact of internal control quality on underinvestment is not significant, at the maturity stage, high quality internal control can inhibit underinvestment significantly, at the recession stage, only in non state-owned company, internal control can inhibit underinvestment significantly, in state-owned company, the relationship is not significant.
\end{abstract}

Keywords: corporate life cycle, internal control, underinvestment

\section{Introduction}

Investment decision is one of the most important corporate financial decisions. Prior research demonstrates a lot about the causes and the effects of overinvestment(Xuesong, Xiaosu, \& Rujing, 2010; Honghui \& Zongjun, 2010), however, in reality there is still a lot of companies facing financial constraints, cash flow difficulties and other issues, so they have to give up good investment opportunities and result in underinvestment. Therefore, in the background of total fixed assets' high growth, the real economy is still full of underinvestment. Prior research also finds that the reasons of underinvestment are financial constraints and various types of agency conflicts (Fazzari, Hubbard, \& Peterson, 1988; Hoshi, Kashyap, \& Scharfstein, 1991; Bertrand \& Mullainathan, 2003; Dyck \& Zingales, 2004).

To achieve corporate contract and re-negotiation, internal control provides stakeholders with reasonable institutional arrangements and control mechanisms for configuring power and duties, balancing incentive and constraint. In theory, internal control can alleviate the conflicts between shareholders and management, the conflicts between major shareholders and minority shareholders inside the company, it also can alleviate the conflicts between shareholders and creditors outside the company, thus ease financial constraints. However, neither in the process of US Securities and Exchange Commission implementing Sarbanes-Oxley(SOX), or China regulatory authorities implementing "Basic Norms of Internal Control", they are both faced with various difficulties, especially strongly resisted by small and medium enterprises. I find in the process of establishing and improving internal control, most companies are lack of initiative, the fundamental reason is the higher cost of setting up effective internal control system, and the benefits arising from the effective internal control are with great uncertainty, so implementation of internal control is not cost-effective completely.

Under the theory of corporate life cycle, I find at different stages of the life cycle, the companies have different organizational structure and operating characteristics, so they have to face different kinds of agency problems and financing environment. Effective internal control can manage various types of agency conflicts so as to ease underinvestment behavior, but also it squeezes the company's cash flow, then influence assets investment. Therefore, under the background of critical financial constraints in China, companies need to game when establishing internal control system. The study tests the impact of internal control quality on underinvestment at different stages of life cycle, in order to provide reference for corporation to improve investment efficiency. 


\section{Prior Literature and Theoretical Analysis}

\subsection{Internal Control Quality and Underinvestment}

Asymmetric information and agency problem are considered the most important reasons of underinvestment behavior in the real economy. In efficient financial environment, natural adjustment of interest rate makes credit funds balance with demand and supply. However, in reality, lenders and borrowers have asymmetric information, credit rationing appears, typical credit rationing causes the company face tight financial constraints which generates the phenomenon of underinvestment (Stiglitz \& Weiss, 1981). Companies generally are unable to raise sufficient funds to expand the scale of investment to the level in perfect competition market. In addition, creditors always have incomplete information, they have to reduce the loan amount or increase lending rates in order to protect the recoverability of loans. Thus, companies are forced to give up some good investment projects that NPV greater than zero because of insufficient funds or high financing cost. Some Chinese research also demonstrates that financial constraint is the main reason leading to underinvestment, thereby supporting the theory of asymmetric information (Feng \& Xing, 2004; Yujun \& Jian, 2007).

Accounting information plays more and more important role on alleviating the problem of asymmetric information in credit market. In the debt contract between companies and banks, companies have to repay the principal and interest to creditors to terminate the contractual relationship with creditors, creditors ask for risk premium due to information asymmetry between creditors and borrowers, the higher the degree of asymmetry, the higher the risk premium, the higher the cost of debt (Jensen \& Meckling, 1976).

Prior study demonstrates effective internal control can ease information asymmetry in the capital market. Debt covenants normally ask for corporate earnings, when business performance can not reach the additional conditions attached with the debt contract, manager has the motivation in order to avoid breaking the debt contract, high quality internal control can monitor the opportunistic behavior of the manager. Five elements of internal control that are control environment, risk assessment, control activities, information and communication, supervision which can monitor management power, then avoid companies reduce the quality of accounting information through earnings management behavior. Accounting to Doyle, Ge, and Mcvay (2007), Ashbaugh, Collins, Kinney, and Larfond (2008), internal control quality has a significant positive correlation with earnings quality. Internal control can influence the accounting information reliability, thereby influence the bank trust the accounting data or not. When the quality of corporate internal control is weak, borrowers may increase adverse selection before signing the contract, the probability of debtors' default behavior is also increased, thereby increase moral hazard, so creditors always work out a more stringent terms to restrict debtors. Many research proved that internal control can ease financial constraints.

Principal-Agent problem is another core element of company underinvestment. Agency conflict between shareholders and managers may result in underinvestment, accounting to Bertrand and Mullainathan (2003), manager has private cost when the company makes investment decision for a new project, manager needs to take greater responsibility for regulation, which will inevitably destroy the manager's original peaceful life, so when a new project brings greater private cost to the manager, they may give up some of projects that NPV greater than zero, lead to underinvestment. Aggarwal and Samwick (2006) also proved the same point. In addition, with the increasing of proportion that major shareholders hold the stock, agency conflict between major shareholders and minority shareholders increase, major shareholders may occupy free cash flow attributable to whole shareholders for personal gains, they tunnel companies by means of providing loan guarantees to affiliates, distributing dividends for themselves, and paying high salary for themselves, which enable companies to give up some valuable investment projects because of insufficient funds.

Companies can alleviate the agency conflict problem by efficiently designing and improving five elements of internal control. Internal environment includes institutional arrangement about the owner, governance and management, effective control environment can ensure rational ownership structure, function of the board of directors and the board of supervisors, reconcile the interest of shareholder and manager by designing executive incentive, in order to alleviate agency conflicts and reduce agency cost. Control activities include separation of incompatible duties, authorization and approval procedural, property protection control, these control activities can halt manager collusion override internal control for self-interested behavior to reduce management agency cost. Communication can reflect the degree of participation of governance layer and management layer, to find corporate failure behavior on internal control system. In addition, internal supervision plays an important role on the board of supervisory, independent directors and the audit committee.

In summary, internal control designs a series of incentive and restrained mechanisms that can effectively suppress kinds of agency problems prevalent in listed companies. So, improving the quality of internal control 
should be able to alleviate the underinvestment behavior.

\subsection{Internal Control Quality and Underinvestment under the Perspective of Life Cycle}

Life cycle theory suggests that companies have different operating characteristics and organizational structure at different stages of life cycle, they face different management crisis, different capital requirement, so the organization structure and corporate governance model are different at different stages of life cycle. Thereby, companies may face different agency problems and different degree of agency cost at different stages of life cycle, and this is bound to affect the investment efficiency and internal control governance efficiency.

Internal control is a kind of system design cost needed, company needs to weigh capital allocation under the background of financing constraints. The most effective internal control should be achieved maximize earnings under the given conditions of input, or input minimize costs under a given earnings. When the cost of establishing and improving internal control increases, the agency cost will decrease, but other cost associated with internal control will increase, therefore, for individual company, the quality of internal control is not the higher the better, but to maintain balance between agency costs and other costs.

The scale of growing enterprise grows gradually, the right of ownership and the right of management separate gradually, so the principal-agent problem appears. Business report and financial system is not perfect at the growing stage, risk response ability is lower, asymmetric information between companies and creditors will lead to corporate financing difficulties, due to the limited fund reserves, companies have to give up positive NPV investment opportunities in spite of expansion demand. Compare to maturity and decline stage, the agency problem at the growing stage is relatively weak, the impact of internal control quality on agency problem is not as obvious, and underinvestment problem caused by lack of funds is serious, financial constraint is the main problem at the growing and expansion process. Excessive investment in internal control will occupy a lot of money, and cause increased opportunity cost and financing cost.

With the growth in scale, companies at the mature stage tend to introduce more professional managers, the agency problem between owners and managers become more serious. Corporations at the stage of maturity period slow down their development tempo gradually, but they still have high economic efficiency, their market position consolidate, rules and regulations have been formed, information system is getting better and better, information asymmetry between corporations and creditors alleviate effectively, external financing conditions are more favorable, increased sales revenue generates a lot of free cash flow, underinvestment phenomenon can be alleviated. Companies at this stage generate a lot of free cash flow, appropriate internal control investment can not lead to increasing financing cost by insufficient funds, and improving the quality of internal control can ease more and more serious agency problems.

The problem of management bureaucracy and selfish departmentalism aggravates when the corporations are at the stage of recession, company-paid consumption phenomenon appears frequently, especially in the state-owned corporations in China. Companies at the stage of recession have passed the maturity stage, they still have high transparency information, and creditors strengthen the supervision and intervention on the corporation, external financing information become worse and the companies have insufficient cash flow. Compared with companies at the growing stage, companies at the recession stage have less investment opportunity, they need to improve internal control to solve governance issues, to seek way out. Therefore, at different stages of corporation development, the impact of internal control quality on underinvestment should be different.

\section{Data Requirement and Variable Measurement}

\subsection{Measuring Underinvestment}

Accounting to Richardson (2006), he puts forward a model to measure investment efficiency, I use the model to measure underinvestment. First, I regress the formula (1) which is used for investment scale, then use the company-level residual of the model to measure investment efficiency, where the positive residual indicates overinvestment, negative residual indicates underinvestment.

$$
\begin{aligned}
& \operatorname{Inv}_{i, t}=a_{0}+a_{1} Q_{i, t-1}+a_{2} \text { Lev }_{i, t-1}+a_{3} \text { Cash }_{i, t-1}+a_{4} \text { Stock }_{i, t-1}+a_{5} \text { Age }_{i, t-1} \\
& +a_{6} \text { Size }_{i, t-1}+a_{7} \text { Inv }_{i, t-1}+\sum \text { Year }+\sum \text { Industry }+\varepsilon_{i, t}
\end{aligned}
$$

Where:

$\operatorname{Inv}_{\mathrm{i}, \mathrm{t}}=$ change in investment during period $\mathrm{t}$,

$\mathrm{Q}_{\mathrm{i}, \mathrm{t}-1}=$ Tobin' $\mathrm{Q}$ at the end of year $\mathrm{t}-1$, 
$\operatorname{Lev}_{\mathrm{i}, \mathrm{t}-1}=$ total liabilities divided by total assets at the end of year $\mathrm{t}-1$,

$\mathrm{Cash}_{\mathrm{i}, \mathrm{t}-1}=$ cash and cash equivalents divided by total assets at the end of year $\mathrm{t}-1$,

StockR $\mathrm{R}_{\mathrm{i}, \mathrm{-}-1}=$ stock returns from year $\mathrm{t}-1$ to year $\mathrm{t}$,

$\mathrm{Age}_{\mathrm{i}, \mathrm{t}-1}=$ years from listing to investment spending,

Size $_{\mathrm{i}, \mathrm{t}-1}=$ natural $\log$ of total assets at the end of year $\mathrm{t}-1$,

Year and industry are dummy variables, residuals of model (1), $\varepsilon_{i, t}$ equals actual investment amount minus expected investment amount, when less than 0 means underinvestment, use absolute value Underinv $v_{i, t}$ to represent.

\subsection{Measuring Internal Control Quality}

I select internal control index issued by Chinese Dibo Enterprise Risk Management Technologies Co. Ltd to evaluate internal control quality. It designs Chinese internal control and risk management database based on its theory and practical experience in the field of internal control and risk management, and use for reference of Audit Analytics Data. The data of this index system are from annual reports data, corporate governance section, important item section, and "internal control self-evaluation report", it builds model based on the objective of internal control, elements of internal control and relevant data, reflects the internal control quality accurately. The database has a certain authority, Ministry of Finance, Security Regulatory Commission use Dibo database in many important reports. Raw data of internal control index is in the range 167-990, in order to eliminate the influence of the size on regression, I calculate the natural logarithm of internal control index to represent internal control quality.

\subsection{Measuring Corporate Life Cycle}

I use combination of cash flow method to determine the stage of life cycle (Dickinson, 2006). The method can reflect the ability to obtain funds, the ability to use funds rationally, and the ability of investment strategy, and overcome the disadvantages of the combined financial index; meantime, it is feasible to organize cash flow data and to avoid subjective intervention. The sample of my study is listed companies, so I combine start-up period and growing up period to the growing stage, combine recession period and termination period to the recession period, the corporation life cycle is divided into growing stage, maturity stage and recession stage. Specific criteria for the classification are shown in Table 1.

\subsection{Model for Testing the Hypothesis}

The first step, I use combination of cash flow method to divide the whole sample into three samples that are growing stage, maturity stage and recession stage.

The second step, I examine the factors of underinvestment at different stages of life cycle. I use the formula(2) to examine internal factors of underinvestment, which is the impact of agency cost on underinvestment; Accounting to Ang, Cole, and Lin (2000), I use management expense ratio and total assets turnover to measure management agency cost. Management expense ratio reflects manager's waste in order to seek their own interest at the interests of shareholders, the higher management expense ratio, the higher the management agency cost. I also use total assets turnover to measure management agency cost, it can reflect agency cost due to management inefficient investment or lazy behavior. The lower the total assets turnover, the higher the management agency cost. I use other receivables to measure agency cost of major shareholders, the more other receivables, the higher agency cost of major shareholders.

$$
\begin{aligned}
& \text { Underinv }_{i, t}=\beta_{0}+\beta_{1} \text { Expense }_{i, t}+\beta_{2} \text { Turnover }_{i, t}+\beta_{3} \text { Tunnel }_{i, t}+\beta_{4} \text { Size }_{i, t}+\beta_{5} \text { Age }_{i, t} \\
& +\beta_{6} \text { Loss }_{i, t}+\beta_{7} \text { FCF }_{i, t}+\beta_{8} \text { Dual }_{i, t}+\beta_{9} \text { Dsize }_{i, t}+\beta_{10} \text { Compensation }_{i, t}+\beta_{11} \text { Mstckhd }_{i, t} \\
& +\beta_{12} \text { Direpro }_{i, t}+\beta_{13} \text { Monisize }_{i, t}+\sum \beta_{i} \text { Ind }_{i}+\sum \beta_{i} \text { Year }_{i}+\varepsilon
\end{aligned}
$$

Where:

Underinv $_{\mathrm{i}, \mathrm{t}}=$ absolute value of the negative residuals calculated by formula (1),

Expense $_{\mathrm{i}, \mathrm{t}}=$ administrative expenses divided by income from operating activities,

Turnover $_{\mathrm{i}, \mathrm{t}}=$ income from operating activities divided by total assets,

Tunnel $_{i, \mathrm{t}}=$ other receivables divided by total assets,

Size $_{\mathrm{i}, \mathrm{t}}=$ the natural logarithm of total assets, 
$\mathrm{Age}_{\mathrm{i}, \mathrm{t}}=$ the length of time the company listed,

$\operatorname{Loss}_{\mathrm{i}, \mathrm{t}}=\mathrm{a}$ dummy variable that is equal to one if the net income is negative during period $\mathrm{t}$, and zero otherwise,

$\mathrm{FCF}_{\mathrm{i}, \mathrm{t}}=$ free cash flows divided by total assets,

Dual $_{i, t}=$ a dummy variable that is equal to one if the executives adjunct chairman or director, and zero otherwise,

Dsize $_{\mathrm{i}, \mathrm{t}}=$ the number of the board of directors,

Compensation $\mathrm{i}_{\mathrm{i}, \mathrm{t}}=$ the natural logarithm of total of the top three executive compensation,

Mstckhd $_{\mathrm{i}, \mathrm{t}}=$ proportion of executive ownership,

Direpro $_{\mathrm{i}, \mathrm{t}}=$ the number of independent members divided by the number of board of directors,

Monisize $_{\mathrm{i}, \mathrm{t}}=$ the number of board of supervisory.

The third step, I use differential analysis method to judge the external factors of underinvestment, that is the impact of financing constraints on underinvestment. I use debt maturity and increased debt to measure financial constraints. The longer the debt maturity, and the greater increased debt, the weaker the company faces financial constraint.

The forth step, I use formula (3) to examine the governance effect of internal control quality on underinvestment.

$$
\begin{aligned}
& \text { Underinv }_{i, t}=\beta_{0}+\beta_{1} \text { ICQ }_{i, t}+\beta_{2} \text { Size }_{i, t}+\beta_{3} \text { Age }_{i, t}+\beta_{4} \text { Loss }_{i, t}+\beta_{5} \text { FCF }_{i, t}+ \\
& \beta_{6} \text { Top }_{i, t}+\beta_{7} \text { Dual }_{i, t}+\beta_{8} \text { Dsize }_{i, t}+\beta_{9} \text { Compensation }_{i, t}+\beta_{10} \text { Mstckhd }_{i, t}+ \\
& \beta_{11} \text { Direpro }_{i, t}+\beta_{12} \text { Monisize }_{i, t}+\sum \beta_{i} \text { Ind }_{i}+\sum \beta_{i} \text { Year }_{i}+\varepsilon
\end{aligned}
$$

Where:

Underinv $_{\mathrm{i}, \mathrm{t}}=$ absolute value of the residuals calculated by formula (1),

$\mathrm{ICQ}_{\mathrm{i}, \mathrm{t}}=$ natural logarithm of internal control index based on Dibo database,

Size $_{\mathrm{i}, \mathrm{t}}=$ the natural logarithm of total assets,

$\mathrm{Age}_{\mathrm{i}, \mathrm{t}}=$ the length of time the company listed,

Loss $_{\mathrm{i}, \mathrm{t}}=$ a dummy variable that is equal to one if the net income is negative during period $\mathrm{t}$, and zero otherwise,

$\mathrm{FCF}_{\mathrm{i}, \mathrm{t}}=$ free cash flows divided by total assets,

Top $1_{\mathrm{i}, \mathrm{t}}=$ the proportion of the largest share,

Dual $_{\mathrm{i}, \mathrm{t}}=$ a dummy variable that is equal to one if the executives adjunct chairman or director, and zero otherwise,

Dsize $_{\mathrm{i}, \mathrm{t}}=$ the number of the board of directors,

Compensation $_{\mathrm{i}, \mathrm{t}}=$ the natural logarithm of total of the top three executive compensation,

Mstckhd $_{i, t}=$ proportion of executive ownership,

Direpro $_{\mathrm{i}, \mathrm{t}}=$ the number of independent members divided by the number of board of directors,

Monisize $_{\mathrm{i}, \mathrm{t}}=$ the number of board of supervisory.

\section{Data and Descriptive Statistics}

I select 2009-2014 Chinese listed companies, and screen the data in accordance with following procedure: (1) exclude financial companies; (2) exclude the missing data sample; (3) exclude ST and PT companies; (4) in order to avoid the effect of extreme data, I do the exception handling with the continuous variable that less than $1 \%$ and more than $99 \%$ quintile observations. I get 2979 underinvestment observations after screening the sample. Data is mainly from CSMAR database, Chinese Dibo database, Sina and Baidu network, part of financial data is from the companies' annual reports.

Table 2 reports the descriptive statistics of main variables. The mean of underinvestment is 0.031 that indicates the existence of underinvestment behavior in China; the maximum of internal control quality is 6.9 , and the minimum of internal control quality is 6.02 , that reveals that there are different internal control quality among different listed companies; the majority of listed companies in the sample is profitable; from the view of corporate governance, the mean of Dual is 0.593 , that reveals executive power of listed companies is large, the maximum of Dsize is 18 , the minimum of Dsize is 5, and the mean of Dsize is 9, the mean of Direpro is 0.369, the minimum of Direpro is 0.25 , the mean of Monisize is 3.703 , that reveals the board of directors and the board 
of supervisory reach the basic system requirements in the sample companies; from the view of management incentive, the mean of Mstckhd is 0.036, the maximum of Mstckhd is 0.7, the minimum of Mstckhd is 0 , the maximum of Compensation is 16.64 , and the minimum of Compensation is 10.31, that reveals there are obvious difference on executive incentive in the sample companies. The maximum, minimum of management expense ratio, total assets turnover and capital occupied by major shareholders are obvious different, that reveals there is much difference on management agency cost and agency cost of major shareholders among sample companies.

\section{Empirical Results}

\subsection{Difference Test}

Table 3 reports non-parametric test about growing stage-maturity stage, growing stage-recession stage, maturity stage-recession stage. I find the level of underinvestment is most serious at the stage of growing period, weakest at the stage of maturity stage, there is significant difference between growing stage with maturity stage, also between recession stage with maturity stage; internal control quality is best at the stage of maturity period, lowest at the stage of recession stage, there is significant difference between growing stage with recession stage, also between maturity stage with recession stage; management expense ratio is highest at the stage of recession period, lowest at the stage of growing period, total assets turnover is lowest at the stage of recession period, highest at the stage of maturity period, reveals agency conflict is higher at the stage of recession period; capital occupied by major shareholders is lowest at the stage of growing period, highest at the stage of recession period, reveals the agency conflict between major shareholders and minority shareholders is weaker at the stage of growing period, stronger at the stage of recession period; besides, other factors as company characteristics, corporate governance, management incentive are different at different stages of life cycle. All of the above lays the foundation for further regression.

\subsection{Underinvestment Motivation Test}

Table 4 reports whether underinvestment companies are facing financing constraints. Chinese companies have particularity in type and structure of ownership, there are significant differences in terms of agency problems, investment and financing decision-making between state-owned companies and non-state-owned companies, so I further divide the sample into state-owned companies and non state-owned companies. There are six groups divided by life cycle and ownership type, debt maturity of the other companies is significantly lower than the optimal sample except state-owned companies in the maturity stage; new loans of all samples are significantly lower than optimal sample. Overall, compared with optimal investment companies, underinvestment companies face more financial constraints, and non-state-owned companies face more financial constraints than state-owned companies.

Table 5 reports the regression result of model (2) about the effects of agency cost on underinvestment in different life cycle. At the growing stage, agency conflict is not factor in both state-owned companies and non-state-owned companies; at the maturity stage, management conflict may cause underinvestment in state-owned companies, conflict between major shareholders and minority shareholders may cause underinvestment in non-state-owned companies; at the recession stage, management conflict, conflict between major shareholders and minority shareholders are factors of underinvestment in state-owned companies, shareholders' occupation is the main factor of underinvestment in non-state-owned companies. It proves that underinvestment phenomenon is not entirely due to financial constraints, underinvestment is mainly caused by financing constraints at the growing stage, and underinvestment is caused by financing constraints and agency conflict at the maturity stage and recession stage.

\subsection{Test of Internal Control Quality on Underinvestment in the View of Life Cycle}

Table 6 reports the regression result of model (3) about the effect of internal control quality on underinvestment at different stages of life cycle. At the growing stage, The impact of internal control quality on underinvestment behavior is not significant in both state-owned companies and non-state-owned companies, as indicated previously, at the growing stage, various types of agency cost is low, lack of funds is the main obstacle to its development, so the input of internal control has limited role on agency cost, but occupies the company's funds, so affects rational investment. At the maturity stage, effective internal control can ease underinvestment significantly, cash flow is sufficient in this period, so adequate internal control input can not lead to increased financing cost caused by funds constraints, and improving the quality of internal control can ease underinvestment behavior caused by agency conflicts. At the recession stage, internal control quality can ease underinvestment only in non-state-owned companies, underinvestment is relatively weak in this period, the degree of underinvestment is more serious in non-state-owned companies, so the impact of internal control quality on underinvestment is not significant in state-owned companies at the stage of recession period. 


\section{Conclusion}

I discuss the impact of internal control quality on underinvestment behavior, divide the sample into the growing stage, the maturity stage and the recession stage according to the method of cash flows combination, examine the factors of underinvestment at different stages of life cycle, and whether there are differences on the impact of internal control quality on underinvestment, the conclusions are as follows:

(1) There are differences on the degree of underinvestment at different stages of life cycle. The degree of underinvestment is highest at the growing stage, lowest at the recession stage; internal control quality is highest at the maturity stage, lowest at the recession stage.

(2) The factors of underinvestment behavior are different at different stage of life cycle. Financial constraint is one of the factors at all stages of life cycle, and non-state-owned sample face more financial constraint than state-owned sample; in addition, at the maturity stage, management proxy conflict can lead to underinvestment in state-owned sample, major shareholder proxy conflict can lead to underinvestment in non-state-owned sample; at the recession stage, management proxy conflict and major shareholder proxy conflict can lead to underinvestment in state-owned sample, major shareholder proxy conflict can lead to underinvestment in non-state-owned sample.

(3) There are differences on the impact of internal control quality on underinvestment at different stages of life cycle. At the growing stage, the impact of internal control quality on underinvestment is not significant, at the maturity stage, improving internal control quality can alleviate the underinvestment behavior significantly; at the recession stage, internal control quality can inhibit underinvestment behavior only in non-state-owned company, the relationship is not significant in state-owned company.

Table 1. Cash flow characteristics of corporate life cycle

\begin{tabular}{|c|c|c|c|c|c|c|c|c|}
\hline \multirow[b]{2}{*}{ Cash flows } & \multicolumn{2}{|c|}{ Growing Stage } & \multirow{2}{*}{$\begin{array}{r}\text { Maturity Stage } \\
\text { Maturity period }\end{array}$} & \multicolumn{5}{|c|}{ Recession Stage } \\
\hline & $\begin{array}{c}\text { Start-up } \\
\text { period }\end{array}$ & $\begin{array}{c}\text { Growing } \\
\text { up }\end{array}$ & & $\begin{array}{c}\text { Recession } \\
\text { period }\end{array}$ & $\begin{array}{c}\text { Recession } \\
\text { period }\end{array}$ & $\begin{array}{c}\text { Recession } \\
\text { period }\end{array}$ & $\begin{array}{c}\text { Termination } \\
\text { period }\end{array}$ & $\begin{array}{c}\text { Termination } \\
\text { period }\end{array}$ \\
\hline $\begin{array}{l}\text { Net cash flows from } \\
\text { operating activities }\end{array}$ & - & + & + & - & + & + & - & - \\
\hline $\begin{array}{l}\text { Net cash flows from } \\
\text { investing activities }\end{array}$ & - & - & - & - & + & + & + & + \\
\hline $\begin{array}{l}\text { Net cash flows from } \\
\text { financing activities }\end{array}$ & + & + & - & - & + & 一 & + & - \\
\hline
\end{tabular}

Table 2. Descriptive statistics for main variables

\begin{tabular}{llllll}
\hline Variable & Means & Median & Max & Min & Std Dev \\
\hline Underinv & 0.031 & 0.023 & 0.441 & $2.255 \mathrm{E}-5$ & 0.034 \\
ICQ & 6.554 & 6.550 & 6.900 & 6.020 & 0.102 \\
Size & 22.149 & 21.954 & 28.280 & 19.290 & 1.352 \\
Age & 10.508 & 11.000 & 21.000 & 2.000 & 5.233 \\
Loss & 0.054 & 0.000 & 1.000 & 0.000 & 0.226 \\
FCF & 0.070 & 0.082 & 0.590 & -0.908 & 0.146 \\
Top1 & 36.801 & 35.23 & 93.61 & 2.197 & 15.692 \\
Dual & 0.593 & 1.000 & 1.000 & 0.000 & 0.492 \\
Dsize & 9.023 & 9.000 & 18.000 & 5.000 & 1.909 \\
Compensation & 13.987 & 13.982 & 16.640 & 10.310 & 0.746 \\
Mstckhd & 0.036 & 0.000 & 0.700 & 0.000 & 0.110 \\
Direpro & 0.369 & 0.333 & 0.667 & 0.250 & 0.052 \\
Monisize & 3.703 & 3.000 & 12.000 & 1.000 & 1.194 \\
Expense & 0.082 & 0.066 & 0.590 & 0.003 & 0.063 \\
Turnover & 0.802 & 0.692 & 2.780 & 0.050 & 0.498 \\
Tunnel & 0.015 & 0.011 & 0.221 & $2.263 \mathrm{E}-5$ & 0.025 \\
\hline
\end{tabular}


Table 3. Difference test of main variable at different stages of life cycle

\begin{tabular}{lcccccc}
\hline \multirow{2}{*}{ Variables } & \multicolumn{3}{c}{ Divided by life cycle } & Z-Statistics \\
\cline { 2 - 7 } Sample & Growing stage & Maturity stage & Recession stage & Growing-Maturity & Growing-Recession Maturity-Recession \\
\hline Underinv & 1465 & 937 & 577 & & & $-2.650^{* * *}$ \\
ICQ & 0.035 & 0.023 & 0.030 & $-5.327 * * *$ & -0.256 & $-4.057^{* * *}$ \\
Size & 6.558 & 6.562 & 6.522 & -0.552 & $-3.492^{* * *}$ & $5.425^{* * *}$ \\
Age & 21.868 & 22.456 & 21.620 & $-4.839^{* * *}$ & -1.174 & $-2.483^{* *}$ \\
Loss & 9.736 & 10.490 & 11.960 & -1.515 & $-3.184^{* * *}$ & $-3.766^{* * *}$ \\
FCF & 0.033 & 0.034 & 0.162 & -0.040 & $-4.635^{* * *}$ & $-6.059^{* * *}$ \\
Top1 & 0.039 & 0.118 & 0.040 & $-5.462^{* * *}$ & $-1.971^{* *}$ & $-5.686^{* * *}$ \\
Dual & 36.712 & 37.837 & 34.705 & $-2.278^{* *}$ & $-4.166^{* * *}$ & $-4.249 * * *$ \\
Dsize & 0.298 & 0.989 & 0.866 & $-14.809^{* * *}$ & $-9.922^{* * *}$ & $-1.844^{*}$ \\
Compensation & 8.994 & 9.220 & 8.765 & -1.568 & -0.757 & $-2.890^{* * *}$ \\
Mstckhd & 13.972 & 14.098 & 13.838 & $-1.954^{*}$ & -1.512 & -0.797 \\
Direpro & 0.028 & 0.054 & 0.031 & -0.032 & -0.981 & -0.860 \\
Monisize & 0.369 & 0.366 & 0.374 & -0.504 & -0.508 & $-9.285^{* * *}$ \\
Expense & 3.564 & 2.954 & 3.872 & $-5.009 * * *$ & $-5.161^{* * *}$ & -1.209 \\
Turnover & 0.082 & 0.092 & 0.096 & $-4.010^{* * *}$ & $-4.110^{* * *}$ & $-3.273^{* * *}$ \\
Tunnel & 0.792 & 0.845 & 0.725 & $-1.799^{*}$ & $-2.023^{* *}$ & $-3.372^{* * * *}$ \\
\hline
\end{tabular}

Note. Asterisks *, **, and *** denote two-tailed (one-tailed when there is a predicted sign) statistical significance at $10 \%, 5 \%$, and $1 \%$ respectively.

Table 4. Difference test of financial restraints between underinvestment sample and optimal Investment Sample

\begin{tabular}{llcccccc}
\hline \multirow{2}{*}{ Stage } & Variables & \multicolumn{3}{c}{ Group } & \multicolumn{3}{c}{ Z-Statistics } \\
\cline { 3 - 7 } & & State & Non-state & Optimal & State-Optimal & Non-state-Optimal & State-Non-state \\
\hline \multirow{2}{*}{ Growing } & Maturity & 0.0749 & 0.0115 & 0.2392 & $-4.724 * * *$ & $-6.001 * * *$ & $-3.134 * * *$ \\
& ICdebt & 0.0234 & 0.0169 & 0.0287 & $-3.750^{* * *}$ & $-5.813 * * *$ & -0.713 \\
\multirow{3}{*}{ Maturity } & Maturity & 0.2439 & 0.1440 & 0.2392 & -0.134 & $-2.323 * *$ & $-2.245 * *$ \\
\multirow{2}{*}{ Recession } & ICdebt & -0.0169 & -0.0219 & 0.0287 & $-3.922 * * *$ & $-5.882 * * *$ & $2.400 * *$ \\
& Maturity & 0.1602 & 0.0922 & 0.2392 & $-2.022^{* *}$ & $-3.461 * * *$ & -0.708 \\
& ICdebt & -0.0006 & -0.0093 & 0.0287 & -1.280 & $-2.803 * * *$ & $-4.382 * * *$ \\
\hline
\end{tabular}

Note. Asterisks *,**, and $* * *$ denote two-tailed (one-tailed when there is a predicted sign) statistical significance at $10 \%, 5 \%$, and $1 \%$ respectively; I range the residuals regressed by the model, make positive residuals of P0-05 and negative residuals P96-100 as optimal investment sample, P5 is the 5th percentile, and so on.

Table 5. Regression of internal factors on underinvestment

\begin{tabular}{lcccccc}
\hline \multirow{2}{*}{ variables } & \multicolumn{3}{c}{ state } & \multicolumn{3}{c}{ Non-state } \\
\cline { 2 - 7 } (Constant) & growing & maturity & recession & growing & maturity & recession \\
& 0.114 & -0.166 & -0.047 & -0.097 & $-0.430^{* * *}$ & $-0.440^{* *}$ \\
Expense & $(1.582)$ & $(-1.278)$ & $(-0.221)$ & $(-0.434)$ & $(-4.104)$ & $(-2.309)$ \\
& 0.026 & $0.018^{* *}$ & $0.001^{*}$ & 0.001 & 0.005 & 0.119 \\
Turnover & $(0.417)$ & $(2.106)$ & $(1.810)$ & $(1.080)$ & $(0.450)$ & $(1.489)$ \\
& $-1.594 \mathrm{E}-4$ & -0.038 & -0.007 & -0.007 & -0.002 & -0.009 \\
Tunnel & $(-0.481)$ & $(-0.875)$ & $(-0.150)$ & $(-1.372)$ & $(-0.850)$ & $(-0.343)$ \\
& 0.001 & 0.011 & $0.470^{* * *}$ & 0.082 & $0.034^{* *}$ & $0.050^{* *}$ \\
Size & $(0.350)$ & $(0.152)$ & $(4.159)$ & $(0.606)$ & $(2.111)$ & $(2.624)$ \\
& -0.003 & -0.002 & $-0.007 *$ & $-0.005 *$ & -0.002 & $0.032^{* * *}$ \\
Loss & $(-1.642)$ & $(-1.148)$ & $(-1.740)$ & $(-1.658)$ & $(-1.048)$ & $(3.622)$ \\
& 0.003 & -0.003 & 0.042 & 0.013 & 0.006 & -0.009 \\
Age & $(0.233)$ & $(-0.372)$ & $(1.132)$ & $(0.767)$ & $(0.746)$ & $(-0.309)$ \\
& $-0.001 *$ & $-6.276 \mathrm{E}-4$ & $-9.331 \mathrm{E}-4$ & 0.001 & $-5.902 \mathrm{E}-5$ & $-6.209 \mathrm{E}-4$ \\
& $(-1.702)$ & $(-1.218)$ & $(-1.058)$ & $(0.929)$ & $(-0.132)$ & $(-0.294)$ \\
\hline
\end{tabular}




\begin{tabular}{|c|c|c|c|c|c|c|}
\hline FCF & $\begin{array}{c}-0.047 * * * \\
(-3.155)\end{array}$ & $\begin{array}{l}-0.037 * \\
(-1.766)\end{array}$ & $\begin{array}{l}0.070 * \\
(1.788)\end{array}$ & $\begin{array}{c}-0.045^{* *} \\
(-2.316)\end{array}$ & $\begin{array}{l}-0.018 * \\
(-1.802)\end{array}$ & $\begin{array}{c}-0.092 * * \\
(-2.400)\end{array}$ \\
\hline Dual & $\begin{array}{c}-0.002 \\
(-0.398)\end{array}$ & $\begin{array}{c}-7.626 \mathrm{E}-4 \\
(-0.108)\end{array}$ & $\begin{array}{c}0.005 \\
(0.491)\end{array}$ & $\begin{array}{c}-0.002 \\
(-0.309)\end{array}$ & $\begin{array}{c}0.002 \\
(0.601)\end{array}$ & $\begin{array}{c}0.015 \\
(0.829)\end{array}$ \\
\hline Dsize & $\begin{array}{c}0.004 * * \\
(2.179)\end{array}$ & $\begin{array}{c}-8.513 E-4 \\
(-0.716)\end{array}$ & $\begin{array}{c}4.258 \mathrm{E}-5 \\
(0.020)\end{array}$ & $\begin{array}{c}0.002 \\
(1.062)\end{array}$ & $\begin{array}{c}0.001 \\
(0.530)\end{array}$ & $\begin{array}{c}2.950 \mathrm{E}-4 \\
(0.063)\end{array}$ \\
\hline Direpro & $\begin{array}{c}0.063 \\
(1.174)\end{array}$ & $\begin{array}{c}-0.074 * * \\
(-2.523)\end{array}$ & $\begin{array}{c}-0.091 \\
(-1.560)\end{array}$ & $\begin{array}{c}0.024 \\
(0.467)\end{array}$ & $\begin{array}{c}-0.035 \\
(-0.871)\end{array}$ & $\begin{array}{c}-0.089 \\
(-0.559)\end{array}$ \\
\hline Mstckhd & $\begin{array}{c}-0.036 \\
(-0.106)\end{array}$ & $\begin{array}{c}-0.043 \\
(-0.112)\end{array}$ & $\begin{array}{c}1.161 \\
(0.647)\end{array}$ & $\begin{array}{c}0.042^{* * *} \\
(2.131)\end{array}$ & $\begin{array}{l}0.022^{*} \\
(1.739)\end{array}$ & $\begin{array}{c}0.018 \\
(0.224)\end{array}$ \\
\hline Compensation & $\begin{array}{c}-0.003 \\
(-0.821)\end{array}$ & $\begin{array}{c}0.001 \\
(0.431)\end{array}$ & $\begin{array}{c}-0.003 \\
(-0.766)\end{array}$ & $\begin{array}{c}-0.003 \\
(-0.721)\end{array}$ & $\begin{array}{c}0.057 * * * \\
(3.345)\end{array}$ & $\begin{array}{c}-0.016 \\
(-1.340)\end{array}$ \\
\hline Monisize & $\begin{array}{c}-0.004 \\
(-1.310)\end{array}$ & $\begin{array}{c}2.479 \mathrm{E}-4 \\
(0.148)\end{array}$ & $\begin{array}{c}-0.091 \\
(-1.560)\end{array}$ & $\begin{array}{c}-0.001 \\
(-0.493)\end{array}$ & $\begin{array}{c}-5.103 \mathrm{E}-4 \\
(-0.248)\end{array}$ & $\begin{array}{c}-0.002 \\
(-0.184)\end{array}$ \\
\hline Sample & 803 & 584 & 337 & 662 & 353 & 240 \\
\hline Adjsted R2 & 0.060 & 0.088 & 0.254 & 0.093 & 0.320 & 0.244 \\
\hline $\mathrm{F}$ & $1.888^{* *}$ & $1.986^{* *}$ & $3.070 * * *$ & $2.170 * *$ & $2.885 * * *$ & $2.360^{* *}$ \\
\hline
\end{tabular}

Note. Asterisks $* * *$, and $* * *$ denote two-tailed (one-tailed when there is a predicted sign) statistical significance at $10 \%, 5 \%$, and $1 \%$ respectively.

Table 6. Regression results of internal control quality on underinvestment at different stages of life cycle

\begin{tabular}{|c|c|c|c|c|c|c|}
\hline \multirow{2}{*}{ variables } & \multicolumn{2}{|c|}{ growing } & \multicolumn{2}{|c|}{ maturity } & \multicolumn{2}{|c|}{ recession } \\
\hline & state & non-state & state & non-state & state & non-state \\
\hline \multirow[t]{2}{*}{ (Constant) } & -0.013 & -0.075 & $-0.201 *$ & $-0.524 * * *$ & 0.037 & -0.415 \\
\hline & $(-0.070)$ & $(-0.333)$ & $(-1.725)$ & $(-3.222)$ & $(0.158)$ & $(-0.467)$ \\
\hline \multirow[t]{2}{*}{ ICQ } & -0.021 & -0.040 & $-0.042 * *$ & $-0.014 * * *$ & -0.028 & $-0.035^{*}$ \\
\hline & $(-0.679)$ & $(-1.177)$ & $(-2.230)$ & $(-3.297)$ & $(-0.752)$ & $(-1.699)$ \\
\hline \multirow[t]{2}{*}{ Size } & $-0.004 *$ & $-0.006 * *$ & $-0.003 *$ & $-6.985 \mathrm{E}-4$ & $-0.010 * * *$ & $0.019 * *$ \\
\hline & $(-1.805)$ & $(-2.074)$ & $(-1.669)$ & $(-1.141)$ & $(-2.796)$ & (2.098) \\
\hline \multirow[t]{2}{*}{ Age } & -0.001 & $3.980 \mathrm{E}-4$ & $-4.980-4 *$ & $-0.001 * *$ & 0.001 & $-6.534 \mathrm{E}-6$ \\
\hline & $(-1.790)$ & $(0.530)$ & $(-1.782)$ & $(-2.457)$ & $(0.198)$ & $(-0.500)$ \\
\hline \multirow[t]{2}{*}{ Loss } & 0.010 & 0.010 & -0.005 & 0.011 & -0.005 & 0.053 \\
\hline & $(0.634)$ & $(0.634)$ & $(-0.663)$ & $(0.912)$ & $(-0.440)$ & $(0.799)$ \\
\hline \multirow[t]{2}{*}{ FCF } & $-0.046^{* * * *}$ & $-0.042 * *$ & $-0.043^{*}$ & $-0.029 *$ & $-0.111 * *$ & $-0.102 * *$ \\
\hline & $(-3.203)$ & $(-2.209)$ & $(-1.813)$ & $(-1.780)$ & $(-2.513)$ & $(-2.472)$ \\
\hline \multirow[t]{2}{*}{ Top1 } & $-3.290 \mathrm{E}-4$ & 0.001 & $5.984 \mathrm{E}-4 * *$ & $8.677 \mathrm{E}-4$ & $-4.034 \mathrm{E}-4 *$ & $-0.001 * * *$ \\
\hline & $(-0.541)$ & $(0.621)$ & (2.533) & $(0.802)$ & $(-1.755)$ & $(-2.762)$ \\
\hline \multirow[t]{2}{*}{ Dual } & -0.003 & -0.002 & -0.004 & 0.001 & -0.001 & 0.003 \\
\hline & $(-0.518)$ & $(-0.347)$ & $(-0.670)$ & $(0.211)$ & $(-0.020)$ & $(0.136)$ \\
\hline \multirow[t]{2}{*}{ Dsize } & $0.004 * *$ & 0.002 & $-9.655 \mathrm{E}-4$ & 0.002 & 0.001 & 0.002 \\
\hline & $(2.017)$ & (1.200) & $(-0.294)$ & $(0.772)$ & $(0.585)$ & $(0.314)$ \\
\hline \multirow[t]{2}{*}{ Compensation } & -0.002 & -0.003 & 0.002 & 0.002 & 0.001 & -0.006 \\
\hline & $(-0.668)$ & $(-0.788)$ & $(0.88)$ & $(0.675)$ & $(0.150)$ & $(-0.477)$ \\
\hline \multirow[t]{2}{*}{ Mstckhd } & -0.058 & $0.049 * *$ & -0.010 & 0.018 & 0.192 & 0.042 \\
\hline & $(-0.172)$ & $(2.360)$ & $(-0.610)$ & (1.213) & $(0.100)$ & $(0.451)$ \\
\hline \multirow[t]{2}{*}{ Direpro } & 0.068 & 0.032 & -0.028 & -0.043 & -0.043 & -0.212 \\
\hline & (1.284) & $(0.622)$ & $(-0.749)$ & $(-0.729)$ & $(-0.790)$ & $(-0.767)$ \\
\hline \multirow[t]{2}{*}{ Monisize } & -0.003 & -0.002 & $3.495 \mathrm{E}-4$ & $-7.845 \mathrm{E}-4$ & 0.002 & -0.002 \\
\hline & $(-1.201)$ & $(-0.824)$ & $(0.580)$ & $(-0.313)$ & $(0.653)$ & $(-0.151)$ \\
\hline Sample & 803 & 662 & 584 & 353 & 337 & 240 \\
\hline Adj-R2 & 0.060 & 0.085 & 0.096 & 0.247 & 0.068 & 0.092 \\
\hline F Value & $2.071 * *$ & $2.241^{* *}$ & $2.147 * *$ & $3.128 * * *$ & 1.549 & 1.481 \\
\hline
\end{tabular}

Note. Asterisks *, **, and *** denote two-tailed (one-tailed when there is a predicted sign) statistical significance at $10 \%, 5 \%$, and $1 \%$ respectively. 


\section{References}

Aggarwal, R., \& Samwick, A. (2006). Empire-builders and shirkers: Investment, firm performance, and managerial incentives. Journal of Corporate Finance, 12, 489-515. http://dx.doi.org/10.1016/j.jcorpfin.2006.01.001

Ang, J., Cole, R. A., \& Lin, J. W. (2000). Agency costs and ownership structure. Journal of Finance, 55, 81-106. http://dx.doi.org/10.1111/0022-1082.00201

Ashbaugh-Skaife, H., Collins, D. W., Kinney, W. R., \& LaFond, R. (2008). The effect of internal control deficiencies and their remediation on accrual quality. The Accounting Review, 83, 217-250. http://dx.doi.org/10.2308/accr.2008.83.1.217

Bertrand, M., \& Mullainathan, S. (2003). Enjoying the quiet life? Corporate governance and managerial preferences. Journal of Political Economy, 111, 1043-1075. http://dx.doi.org/10.1086/376950

Dickinson, V. (2006). Future profitability and the role of firm life cycle. Fisher School of Accounting, University of Florida, USA.

Doyle, J. T., GE, W., \& McVay, S. (2007). Accruals quality and internal control over financial reporting. The Accounting Review, 82, 1141-1170.http://dx.doi.org/10.2308/accr.2007.82.5.1141

Dyck, A., \& Zingales, L. (2004). Private benefits of control: an international comparison. Journal of Finance, 59, 537-600. http://dx.doi.org/10.1111/j.1540-6261.2004.00642.x

Fazzari, S., Hubbard, G., \& Peterson, B. (1988). Financing constraint and corporate investment. Brookings Papers on Economic Activity, 1, 141-195. http://dx.doi.org/10.2307/2534426

Feng, W., \& Xing, L. (2004). Impact of financing constraints, uncertainty on investment behavior. Economic Science, 2, 35-42.

Honghui, Z., \& Zongjun, W. (2010). Government intervention, government targets and overinvestment in state-owned listed companies. Nankai Business Review, 3, 101-108.

Hoshi, T., Kashyap, A., \& Scharfstein, D. (1991). Corporate structure, liquidity, and investment: Evidence from Japanese industrial groups. Quarterly Journal of Economics, 106, 33-60. http://dx.doi.org/10.2307/2937905

Jensen, M. C., \& Meckling, W. H. (1976). Theory of the firm: Managerial behavior, agency costs, and capital structure. Journal of Financial Economics, 3, 305-360. http://dx.doi.org/10.1016/0304-405X(76)90026-X

Richardson, S. (2006). Over-investment of Free Cash Flow. Review of Accounting Studies, 11, 159-189. http://dx.doi.org/10.1007/s11142-006-9012-1

Stiglitz, J. E., \& Weiss, A. (1981). Credit Rationing and markets with imperfect information. American Economic Review, 71, 393-410.

Xuesong, T., Xiaosu, Z., \& Rujing, M. (2010). Government intervention, GDP growth and overinvestment in local state-owned enterprises. Journal of Financial Research, 8, 33-48.

Yujun, L., \& Jian, C. (2007). Investment-cash flow sensitivity: Financial constraints or agency cost? Journal of Finance and Economics, 2, 37-46.

\section{Copyrights}

Copyright for this article is retained by the author(s), with first publication rights granted to the journal.

This is an open-access article distributed under the terms and conditions of the Creative Commons Attribution license (http://creativecommons.org/licenses/by/3.0/). 